\title{
Seasonal Abundance and Susceptibility of Faba Bean Varieties to Infestation with Liriomyza trifolii (Burgess) and Empoasca Spp. in Relation to Chemical and Biochemical Components \\ Aml B. Abou -Elkassem \\ Sakha Agricultural Research Station, Plant Protection Research Institute , Kafr El-Sheikh ,ARC ,Egypt.
}

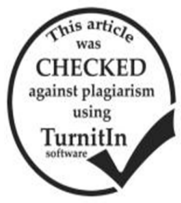

ABSTRACT

Field studies were carried out at the experimental farm of Sakhaa, Agricultural Research Station, Kafr El-Sheikh Governorate during 2014/2015 and 2015/2016 faba bean seasons. Results showed that population of liriomyza trifolii larvae had 3-4 peaks on faba bean varieties in the frist season ,and 2-3 peak in the second season. peaks occurred in January, February and March in both seasons, with the highest one in March . In the frist season, the highest average number of L. trifolii larvae was recorded on Giza 3 variety with 58.00 larvae / 30 leaflets, while the lowest one was on Misr1 variety, with an average of 45.22 larvae/30 leaflets. In the second season, an opposite the highest average number of the larvae was recorded on Misr1 variety with an average of 49.35 larvae/30 leaflets, while the lowest average number on Sakha 4 with an average 30.52 larvae $/ 30$ leaflets. Statistical analysis revealed nonsignificant and significant differences among the 6 tested varieties to infestation with L. trifolii larvae in the first and second seasons, respectively. Concerning leafhoppers, Empoasca spp. population, there were 2-3 peaks on different faba bean varieties during December, January, February or March in both seasons. The highest peak was recorded in March in both seasons . The highest average number of Empoasca spp. (nymphs and adults ) was recorded on Giza 40 variety with an average of 58.55 indiv. $/ 30$ leaflets . the lowest average number of Empoasca spp.was recorded on Sakhaa 3 variety with an average of 42.88 indiv ./30 leaflets in the first season. the opposite occurred in the second season ,Sakha3 showed the highest average number of jassids with an average of 35.83 indiv. /30 leaflets . the lowest one was Sakha2 variety with an average of 29.38 indiv. $/ 30$ leaflets. Statistical analysis showed significant and nonsignificant differences among the 6 tested varieties to infestation with Empoasca spp. in the first and second seasons, respectively. Sakha4 variety showed the highest content of total carbohydrates (52.01\%), Silica (2.7\%) and chlorophyll (42.2 ppm) and lowest content of protein (16.7\%) and lipids $(0.93 \%)$ which had the lowest average of two seasons for $L$. trifolii larvae. Giza3 showed the highest content of protein $(20 \%)$ and silica $(2.7 \%)$ and lowest content of carbohydrates(46.8\%) and chlorophyll $(36 \mathrm{pmm})$. Sakha2 contain the highest content of lipids $(2.04 \%)$ and lowest content of silica $(1.4 \%)$ and phenol $(0.473 \%)$, which had the lowest average of two seasons for Liriomyza trifolii and Empoasca spp. (43larvae and 36.6 indiv./30leaflets, respectively ). Giza40 showed the highest content of phenol $(0.583 \%)$ which had the highest average number of two seasons for L. trifolii larvae (50.5larvae/ 30 leaflets ). Results showed that L. trifolii larvae number correlated insignificantly negative with carbohydrates and chlorophyll in both seasons, in addition to protein and silica in the second season. Positive insignificant correlation with lipids and phenol in both seasons .Empoasca spp .population correlated positive insignificant with carbohydrates, silica, phenol and chlorophyll in the first season, but negative insignificant with carbohydrates ,phenol and chlorophyll in the second season. Results revealed that the activities of antioxidant catalase enzymes (CAT) increased in leaves under insect infestation stress. The responses of CAT activity in some tolerant varieties such as Sakha2 and Sakha4 for infestation by $L$. trifolii and Empoasca spp. the highest activity of peroxidase enzymes (Pox) was observed in the tolerant varieties such as Sakha2 and Sakha4 varieties which possessed the highest tolerance to infestation stress among the 6 varieties for $L$. trifolii and Empoasca spp.. CAT enzymes showed the highest rate of activity changes under infestation stress than of Pox activity. Population of L.trifolii larvae correlated insignificantly positive with catalase and peroxidase enzymes in the first season, while positive significant with catalase and negative significant with peroxidase enzymes in the second season. Population of Jassids showed negative significant correlation with CAT and $\mathrm{POX}$ in the first season, while negative nonsignificant in the second season.

\section{INTRODUCTION}

Faba bean (Vicia faba L.) is one of the most important food crops in Egypt. It ranks the first food legume and considered the main source of plant protein. It is attacked by a large number of insect pests causing damage, among of which are the leaf miners, liriomyza trifolii (Burgers) and leafhopper, Empoasca spp. (Metwally et al., 1997, Abou- Attia, et al., 2013 and Bassiony et al., 2017).

Faba bean varieties differ in the susceptibility to the previous insect pests infestation due to differences in morphological and chemical characters .The resistant varieties could be used as an item in the integrated pest, management programs (Abou - Attia , 2006; Awadalla et al., 2013 and Abou-Attia et al 2013).

The acceptance or rejection of a host plant occurs after probing process, , based on its behavioral responses to plant features (Calvetti \& Remotti, 1998). These features may be morphological, physical and chemical (Bernays, 1999). Gamieh and El-Basuony (2001) indicated that the leaf hair density and leaf contents of photosynthetic pigments, leaf moisture, nitrogen, phosphorus and potassium and other physical and chemical properties may have a pronounced effect in the susceptibility of soybean to infestation with sucking pests .

Antioxidant enzymes are related to the tolerance to various abiotic stresses. To protect against oxidative stresses, plant cells produce both antioxidant enzymes such as peroxidase (Pox) and catalase (CAT) enzymes (Mittler, 2002).

Therefore, the present study aimed to throw the light on the population density of the leafminer, liriomyza trifolii and leafhopper, Empoasca spp. on some faba bean varieties and study the relationship between chemical, biochemical components and chlorophyll content of faba bean varieties and insect pest infestation.

\section{MATERIALS AND METHODS}

Field studies were carried out at the experimental farm of Sakhaa Agriculture Research station, Kafr ElSheikh region during two successive faba bean seasons; $2014 / 2015$ and $2015 / 2016$ to study the population density and host preference of the leafminers, Liriomyza trifolii and leafhopper, Empoasca spp. on some faba bean varieties and relationship between chemical, biochemical components and chlorophyll content of faba bean varieties and insect pest infestation. 


\section{1- Liriomyza trifolii}

Six varieties were assigned for the current study. Varieties of faba bean were Sakha 2 , Sakha 3, Sakha 4, Misr 1, Giza 3 and Giza 40.

The varieties were sown on $1^{\text {st }}$ November in both seasons; 2014/2015 and 2015/2016. The experimental area (about one feddan) was divided into 18 plots (6 varieties $\mathrm{X} \quad 3$ replications each) in a complete randomized block design. All agricultural practices were done without pesticidal treatments throughout the two growing seasons.

Weekly samples of 30 leaflets for each variety were randomly picked up from three levels of plants. The collected leaflets were placed in paper bags and transferred to the laboratory. Numbers of harboured larvae were counted and recorded.

2- Leafhoppers, Empoasca spp.

To study the population fluctuation of faba bean leafhoppers, Empoasca spp. under field condition of Kafr El- Sheikh Region, The same area and varieties were used. Weekly samples of 30 leaflets per variety were chosen at random and number of nymphs and adults of leafhoppers were directly recorded in the field by a suitable lens.

\section{Faba bean components:}

Analysis of faba bean varieties were conducted at Mansoura laboratory, Soil, Water and Environment Research Institute,. Agric. Res. Center Egypt.

Total carbohydrates, total protein, total lipids, silica, and total phenols were calculated by the method of Hedge and Hafreites (1962). Jones et al.(1991) A.O.A.C (1984) APHA (1992) and Malick and Singh (1980), respectively.

Enzymes activity assay:

Catalase (CAT) and Peroxidase (Pox) activity were determined, in the infested and uninfested leaves of 6 faba bean varieties, as CAT enzyme activity was determined in the homogenates by measuring the decrease in absorpation at $240 \mathrm{~nm}$ in a $3 \mathrm{ml}$ of reaction mixture containing $0.16 \mathrm{ml}$ of $10 \% \mathrm{w} / \mathrm{v} \mathrm{H}_{2} \mathrm{O}_{2}$ diluted to $100 \mathrm{ml}$ with $0.067 \mathrm{M}$ phosphate buffer and $0.1 \mathrm{ml}$ of enzyme extract, according Sadasivam and Manickam (1996). Pox activity was spectrophotometrically measured using guaiacol $/ \mathrm{H}_{2} \mathrm{O}_{2}$ as substrate according Lobarzewski et al. (1990) . Chlorophyll was determined by using chlorophyll meter, model No. SPAD - 502 made by Minolta Co.

Statistical analysis:

Data were subjected to ANOVA, and variable means were compared using Duncan's Multiple Range Test (1955) at 5\% level and simple correlation

\section{RESULTS AND DISCUSSION}

\section{Liriomyza trifolii larvae a.Seasonal abundance}

Results in table (1) show the seasonal abundance of the total number of L.trifolii larvae on faba bean plants during of 2014/2015 and 2015/2016. Seasons

In the first season, there were 3-4 peaks on six varieties of faba bean, they occurred in December, January, February and March. The third peak (in March) was the highest one.
Table 1. Number of faba bean leafminer L.trifolii larvae per 30 leaflets on faba bean varieties at Kafr El-Sheikh, 2014/2015

\begin{tabular}{lcccccc}
\hline Sampling & Sakha & Sakha & Sakha & Misr & Giza & Giza \\
date & $\mathbf{2}$ & $\mathbf{3}$ & $\mathbf{4}$ & $\mathbf{1}$ & $\mathbf{3}$ & $\mathbf{4 0}$ \\
\hline Dec. 6 & 8 & 9 & 8 & 7 & 8 & 5 \\
13 & 11 & 17 & 15 & 9 & 12 & 11 \\
20 & 12 & 20 & 18 & 17 & 15 & 18 \\
27 & 14 & 20 & 22 & 20 & 19 & 17 \\
\hline Jan.3 & 19 & 23 & 27 & 23 & 23 & 21 \\
10 & 31 & 32 & 31 & 29 & 62 & 46 \\
17 & 39 & 40 & 66 & 45 & 25 & 50 \\
24 & 52 & 49 & 48 & 18 & 38 & 64 \\
31 & 62 & 63 & 49 & 53 & 74 & 43 \\
\hline feb. 7 & 44 & 77 & 64 & 89 & 53 & 58 \\
14 & 23 & 57 & 70 & 112 & 40 & 96 \\
21 & 35 & 48 & 49 & 72 & 67 & 59 \\
28 & 88 & 96 & 58 & 48 & 83 & 79 \\
\hline Mar.7 & 71 & 73 & 89 & 103 & 79 & 92 \\
14 & 94 & 139 & 123 & 155 & 151 & 138 \\
21 & 72 & 94 & 93 & 118 & 144 & 82 \\
28 & 146 & 152 & 71 & 89 & 133 & 87 \\
Apr.4 & 8 & 25 & 23 & 31 & 18 & 17 \\
\hline Total & 829 & 1014 & 924 & 814 & 1044 & 983 \\
\hline Mean $\neq$ & $46.1 \neq$ & $56.33 \neq$ & $51.33 \neq$ & $45.22 \neq$ & $58 \neq$ & $54.6 \neq$ \\
SE & $6.3 \mathrm{a}$ & 3.4 a & 6.3 a & 3.4 a & 4.6 a & 5.7 a \\
\hline Means followed by the same letter are not significantly different at \\
0.05 level of probability (Dancun's Multiple Range Test 1955).
\end{tabular}

Data presented in Table (2) and Fig (2) show the number of leafminer larvae during the second season $2015 / 2016$. The larval population in the second season was almost lowest than that recorded in the first season. The population of larvae peaked almost two or three times on all tested varieties. The Peaks occurred in January, February and March, Also, the peak of March is the highest peak of population larvae for L.trifolii

Table 2. Number of faba bean leafminer L.trifolii larvae per 30 leaflets on faba bean varieties at Kafr El-Sheikh, 2015/2016

\begin{tabular}{|c|c|c|c|c|c|c|}
\hline $\begin{array}{l}\text { Sampling } \\
\text { date }\end{array}$ & $\begin{array}{c}\text { Sakha } \\
2 \\
\end{array}$ & $\begin{array}{c}\text { Sakha } \\
3\end{array}$ & $\begin{array}{c}\text { Sakha } \\
4 \\
\end{array}$ & $\begin{array}{c}\text { Misr } \\
1\end{array}$ & $\begin{array}{c}\text { Giza } \\
3\end{array}$ & $\begin{array}{c}\text { Giza } \\
40\end{array}$ \\
\hline Dec.7 & 4 & 7 & 6 & 8 & 8 & 9 \\
\hline 14 & 9 & 13 & 12 & 12 & 10 & 10 \\
\hline 21 & 12 & 19 & 18 & 27 & 15 & 22 \\
\hline 28 & 15 & 23 & 21 & 22 & 31 & 29 \\
\hline Jan.4 & 32 & 23 & 22 & 18 & 21 & 18 \\
\hline 11 & 27 & 49 & 18 & 24 & 30 & 31 \\
\hline 18 & 28 & 33 & 21 & 48 & 33 & 49 \\
\hline 25 & 45 & 38 & 23 & 61 & 41 & 63 \\
\hline Feb.1 & 51 & 22 & 33 & 40 & 25 & 44 \\
\hline 8 & 38 & 32 & 45 & 34 & 56 & 58 \\
\hline 15 & 41 & 41 & 14 & 63 & 32 & 49 \\
\hline 22 & 73 & 53 & 31 & 45 & 32 & 33 \\
\hline Mar.1 & 64 & 61 & 63 & 69 & 51 & 72 \\
\hline 8 & 98 & 127 & 54 & 151 & 117 & 147 \\
\hline 15 & 104 & 136 & 102 & 112 & 95 & 96 \\
\hline 22 & 37 & 52 & 33 & 95 & 45 & 49 \\
\hline 29 & 1 & 8 & 3 & 10 & 15 & 10 \\
\hline Total & 679 & 737 & 519 & 839 & 657 & 789 \\
\hline Mean $\neq$ & $39.9+$ & $43.4 \neq$ & $30.5 \neq$ & $49.4+$ & $38.6 \neq$ & $46.4 \neq$ \\
\hline $\mathrm{SE}$ & $5.1 \mathrm{ab}$ & $1.7 \mathrm{ab}$ & $5.1 \mathrm{~b}$ & $5.7 \mathrm{a}$ & $5.7 \mathrm{ab}$ & $2.8 \mathrm{a}$ \\
\hline
\end{tabular}
0.05 level of probability (Dancun's Multiple Range Test 1955).

Our results are in agreement with those obtained by EL- Samahy (2008) who recorded three peaks of L.trifolii on faba bean plants by the second week of February and 
March and the fourth week of March. Also, Ibrahim (2008) reported that L.congesta had three peaks on faba bean. The first peak occurred during January, the second one occurred on February $23^{\text {rd }}$, while the third peak occurred on March $22^{\text {nd }}$. El-Mashaly (2013) showed that L.congesta larvae had two or three peaks during the first and second season. Also, Hatem (2014) showed that population of L.trifolii had three peaks. The first peak occurred on February and the second peak on March, but the third peak was recorded in April during the first season of the study.

\section{b. Susceptibility of faba bean varieties to infestation:}

Results presented in Table $(1,2)$ and Fig $(1,2)$ show the average number of L.trifolii larvae on faba bean varieties during two seasons 2014/2015 and 2015/2016.

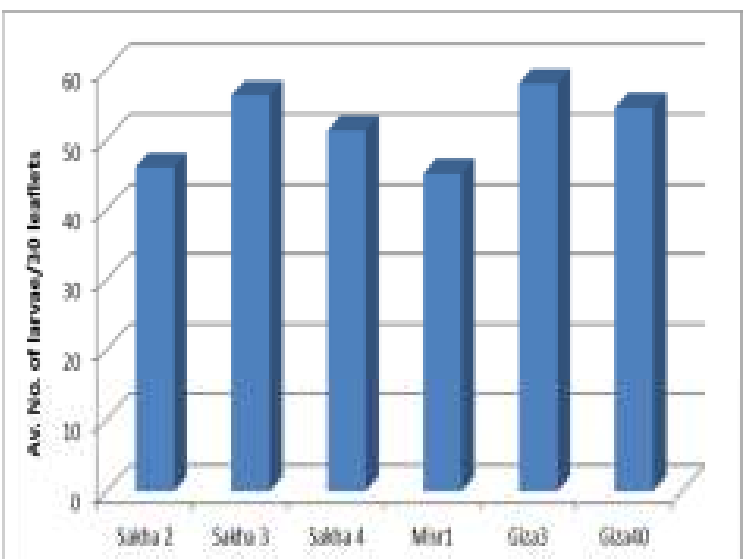

Fig. 1. Average number of $L$. trifolii larvae per 30 leaflets on faba bean varieties at Kafr El- Sheikh 2014/2015 season.

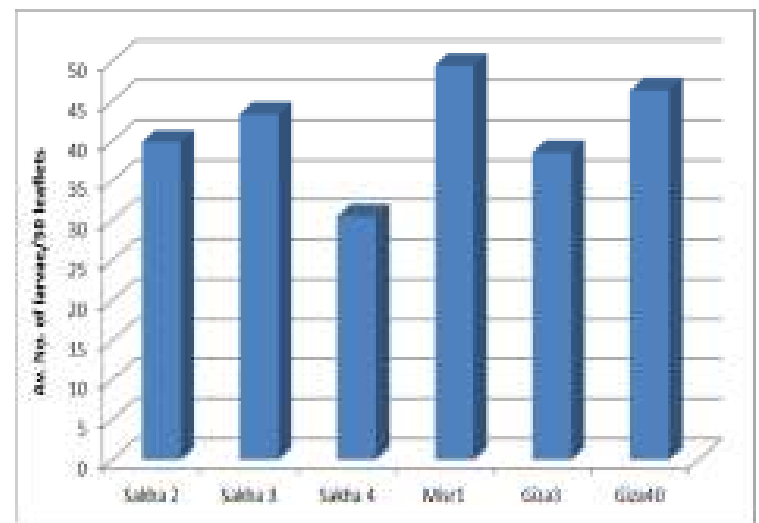

Fig. 2. Average number of $L$. trifolii larvae per 30 leaflets on faba bean varieties at Kafr El- Sheikh 2015/2016 season.

In the first season, the highest average number of L. trifolii larvae was recorded on Giza 3 variety with an average of 58.00 larvae /30 leaflets followed by Sakha 3 with average 56.33 larvae/30 leaflets and Giza 40 with average 54.61 larvae/30 leaflets. While the lowest average number of leafminer larvae was recorded on Misr 1 variety with an average of 45.22 larvae /30 leaflets. Statistical analysis showed nonsignificant differences among the 6 tested varieties to infestation with L.trifolii in the first season.

In the second season, an opposite, the highest average number of L.trifolii larvae was recorded on Misr1 variety with an average of 49.35 larvae/30 leaflets followed by Giza 40 with an average of 46.41 larvae/30 leaflets and Sakha 3 with an average of 43.35 larvae/30 leaflets while the lowest average number of leafminer larvae was recorded on Sakha 4 with an average of 30.52 larvae/30 leaflets. Statistical analysis showed significant differences among the 6 tested varieties to infestation with $L$.trifolii in the second season.

Our results are similar to those obtained by Mesbah and Sherif (1994) who indicated that Giza 461 and Giza 3 proved to be the most susceptible varieties to infestation with L.trifolii with number of larvae ranging between 79.22 and 155.91 per 100 faba bean leaflets ElMashaly (2013) showed that the highest average number of L.congesta larvae was recorded on Giza 3 variety with an average of $157.6 \pm 3.4$ larvae / 100 leaflets followed by Sakha 3 variety while the lowest average number of leaf miner was recorded on Sakha 2 variety with an average of 91.6 \pm 2.3 larvae /100 leaflets. The same trend was recorded in the second season.

Bastawisy et al. (1998) found that Giza 3 was highly susceptible to leafminer in both seasons, while lines $1.8415 / 797 / 92$ and L848/1428/92 were least susceptible.

\section{The leafhoppers, Empoasca spp.}

\section{a. Seasonal abundance:}

Results show the seasonal abundance of the total number of Empoasca spp. (nymphs and adults) on faba bean plants during two successive seasons of 2014/2015 and 2015/2016.

Data presented in Table (3) and illustrated in Fig. (3) in the first season $2014 / 2015$ show that the population of Empoasca ssp. had 2-3 peaks on six varieties of faba bean and increased gradually forming the peaks during December, January, February and March.

Table 3. Number of faba bean Empoasca spp. per 30 leaflets on faba bean varieties at Kafr ElSheikh 2014/2015

\begin{tabular}{|c|c|c|c|c|c|c|}
\hline $\begin{array}{l}\text { Sampling } \\
\text { date }\end{array}$ & $\begin{array}{c}\text { Sakha } \\
2 \\
\end{array}$ & $\begin{array}{c}\text { Sakha } \\
3 \\
\end{array}$ & $\begin{array}{c}\text { Sakha } \\
4 \\
\end{array}$ & $\begin{array}{c}\text { Misr } \\
1\end{array}$ & $\begin{array}{c}\text { Giza } \\
\mathbf{3} \\
\end{array}$ & $\begin{array}{c}\text { Giza } \\
40 \\
\end{array}$ \\
\hline Dec.7 & 9 & 10 & 10 & 11 & 12 & 8 \\
\hline 14 & 22 & 18 & 16 & 17 & 15 & 15 \\
\hline 21 & 53 & 39 & 35 & 41 & 39 & 47 \\
\hline 28 & 28 & 15 & 13 & 21 & 19 & 22 \\
\hline Jan.4 & 33 & 29 & 34 & 22 & 45 & 43 \\
\hline 11 & 54 & 33 & 68 & 28 & 51 & 73 \\
\hline 18 & 79 & 42 & 105 & 98 & 105 & 112 \\
\hline 25 & 88 & 65 & 83 & 61 & 67 & 93 \\
\hline$\overline{\text { Feb.1 }}$ & 110 & 32 & 105 & 44 & 50 & 120 \\
\hline 8 & 26 & 68 & 71 & 77 & 70 & 122 \\
\hline 15 & 49 & 81 & 95 & 115 & 64 & 92 \\
\hline 22 & 66 & 73 & 81 & 110 & 54 & 78 \\
\hline Mar.1 & 30 & 38 & 49 & 140 & 105 & 46 \\
\hline 8 & 55 & 103 & 62 & 98 & 88 & 53 \\
\hline 15 & 41 & 62 & 52 & 59 & 61 & 59 \\
\hline 22 & 32 & 49 & 33 & 52 & 19 & 37 \\
\hline 29 & 14 & 16 & 21 & 32 & 8 & 34 \\
\hline Total & 789 & 772 & 933 & 1026 & 872 & 1054 \\
\hline Mean $=$ & $43.8 \neq$ & $42.9 \neq$ & $51.8 \neq$ & $57 \neq$ & $48.4=$ & $58.6=$ \\
\hline SE & $2.8 \mathrm{ab}$ & $1.1 \mathrm{~b}$ & $5.7 \mathrm{ab}$ & $4.0 \mathrm{ab}$ & $4.6 \mathrm{ab}$ & $6.3 a$ \\
\hline
\end{tabular}

Means followed by the same letter are not significantly different at 0.05 level of probability (Dancun's Multiple Range Test 1955). 
Data in Table (4) and Fig (4) show the number of Empoasca spp. during the second season 2015/2016. Results revealed that the leafhopper population was almost lowest than that recorded in the first season. The population of leafhoppers had 2-3 peaks on all tested (six) varieties. Peaks occurred on December, January, February and March.

Results are in agreement with those obtained by Helal et al. (1997) who found two peaks for jassids on February $12^{\text {th }}$ and March $16^{\text {th }}$ on all tested varieties and breeding lines. El- Mashaly (2013) found one or two peaks for the leafhoppers, Empoasca spp. on faba bean plants. El-Gindy (2002) recorded two peaks for Empoasca spp. on faba bean plants at the $2^{\text {nd }}$ week of December and the $3^{\text {rd }}$ week of February, respectively. Hatem (2014) showed that Empoasca spp. had two peaks in 2010/2011 season, while in the second season $(2011 / 2012)$, four peaks were recorded.

Table 4. Number of faba bean Empoasca spp. per 30 leaflets on faba bean varieties at Kafr ElSheikh 2015/2016

\begin{tabular}{|c|c|c|c|c|c|c|}
\hline $\begin{array}{l}\text { Sampling } \\
\text { date }\end{array}$ & $\begin{array}{c}\text { Sakha } \\
2 \\
\end{array}$ & $\begin{array}{c}\text { Sakha } \\
3 \\
\end{array}$ & $\begin{array}{c}\text { Sakha } \\
4 \\
\end{array}$ & $\begin{array}{c}\text { Misr } \\
1 \\
\end{array}$ & $\begin{array}{c}\text { Giza } \\
\mathbf{3} \\
\end{array}$ & $\begin{array}{c}\text { Giza } \\
40 \\
\end{array}$ \\
\hline Dec.6 & 13 & 18 & 11 & 23 & 24 & 21 \\
\hline 13 & 33 & 24 & 23 & 29 & 37 & 29 \\
\hline 20 & 34 & 38 & 35 & 41 & 42 & 47 \\
\hline 27 & 39 & 79 & 68 & 71 & 53 & 62 \\
\hline Jan.3 & 45 & 56 & 32 & 54 & 50 & 48 \\
\hline 10 & 42 & 43 & 36 & 43 & 31 & 46 \\
\hline 17 & 5 & 4 & 8 & 12 & 13 & 17 \\
\hline 24 & 32 & 23 & 19 & 9 & 10 & 9 \\
\hline 31 & 21 & 18 & 23 & 27 & 18 & 22 \\
\hline Feb.7 & 21 & 25 & 20 & 15 & 15 & 11 \\
\hline 14 & 6 & 12 & 14 & 8 & 5 & 23 \\
\hline 21 & 8 & 11 & 13 & 7 & 2 & 12 \\
\hline 28 & 21 & 27 & 18 & 39 & 41 & 24 \\
\hline Mar.7 & 37 & 32 & 74 & 63 & 75 & 94 \\
\hline 14 & 40 & 48 & 69 & 59 & 67 & 23 \\
\hline 21 & 49 & 53 & 44 & 63 & 50 & 22 \\
\hline 28 & 62 & 105 & 34 & 32 & 43 & 24 \\
\hline Apr.4 & 21 & 29 & 17 & 14 & 18 & 16 \\
\hline Total & 529 & 645 & 558 & 609 & 594 & 550 \\
\hline$\overline{\text { Mean}} \neq$ & $29.4 \neq$ & $35.8 \neq$ & $31 \neq$ & $33.8 \neq$ & $33 \neq$ & $30.6 \neq$ \\
\hline SE & $5.1 \mathrm{a}$ & $2.8 \mathrm{a}$ & $2.8 \mathrm{a}$ & $4.6 \mathrm{a}$ & $1.7 \mathrm{a}$ & $6.3 \mathrm{a}$ \\
\hline
\end{tabular}

Means followed by the same letter are not significantly different at 0.05 level of probability (Dancun's Multiple Range Test 1955).

\section{b. Susceptibility of faba bean varieties to infestation:}

Results in Tables $(3,4)$ and Fig. $(3,4)$ show the average numbers of Empoasca spp. (nymphs and adults) on faba bean varieties during two seasons 2014/2015 and 2015/2016.

In the first season, the highest average number of Empoasca spp. (nymphs and adults) was recorded on Giza 40 variety with an aveage of 58.55 individuals $/ 30$ leaflets followed by Misr 1 variety with an average of 57.00 individuals /30 leaflets, Sakha 4 with an average of 51.83 individuals / 30 leaflets. While the lowest average number of Empoasca spp. was recorded on Sakha3 variety with an average 42.88 individuals $/ 30$ leaflets. Statistical analysis indicated that significant differences among the 6 tested varieties to infestation with Empoasca spp. in the first season.
In the second season, an opposite, the highest average number of Empoasca spp (Nymphs \& adults) was recorded on Sakha3 variety with an average 35.83 individuals / 30 leaflets followed by Misr 1, Variety with an average 33.83 individuals / 30 leaflets and Giza 3 variety with an average of 33.00 individuals / 30 leaflets while the lowest average number of Empoasca spp. was recorded on Sakha2 variety with an average 29.38 individuals / 30 leaflets. Statistical analysis showed nonsignificant differences among the 6 tested varieties to infestation with Empoasca spp. in the second season .

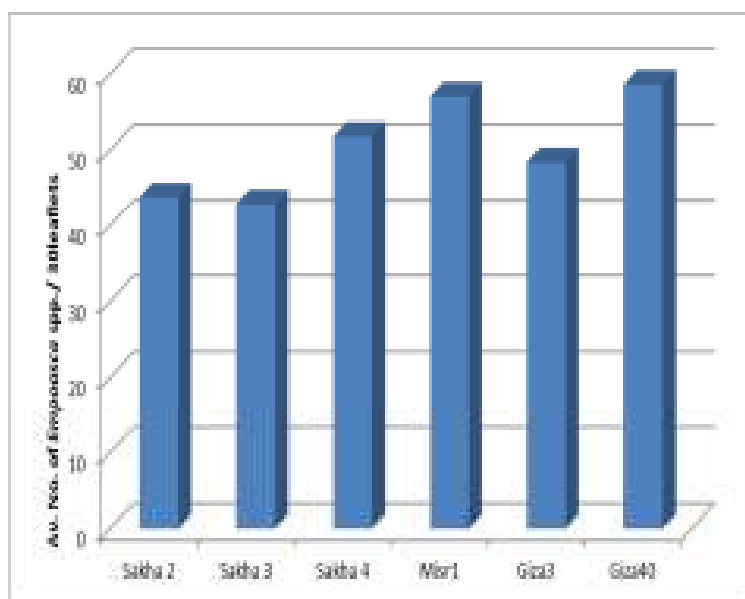

Fig. 3. Average number of Empoasca spp per 30 leaflets on faba bean varieties at Kafr El- Sheikh 2014/2015 season.

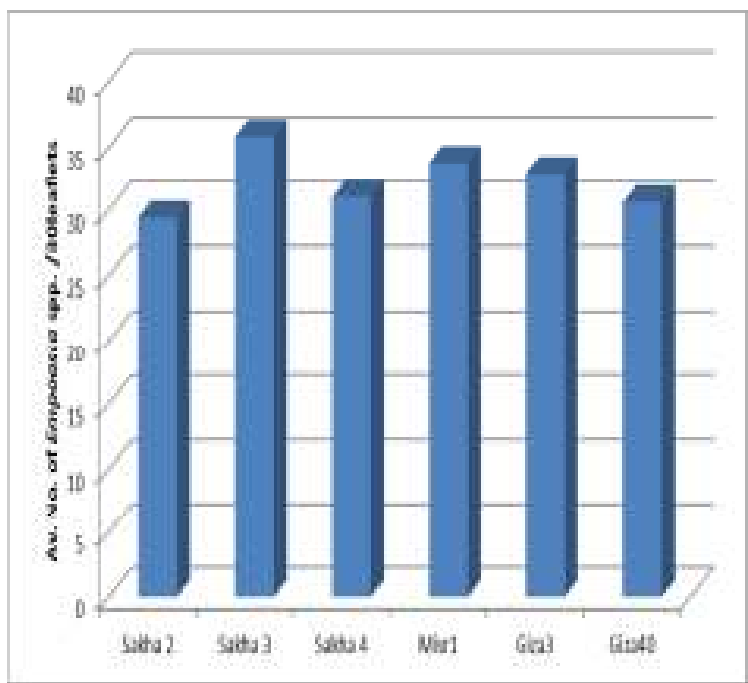

Fig. 4. Average number of Empoasca spp per 30 leaflets on faba bean varieties at Kafr ElSheikh 2015/2016 season

Results are similar to El-Mashaly (2013) showed that the highest average number Empoasca spp .was recorded on Giza3 variety with an average of $70.00 \neq 8.71$ individuals / 100 leaflets followed by Sakha 4 variety. While the lowest average number of leafhopper was recorded on Sakha2 variety with an average of $44.33 \neq$ 7.88 individuals / 100 leaflets.

Hatem (2014) indicated that the highest number of Empoasca spp . was recorded on Sakha 1 variety with an average of 100.25 individuals / 5 plants. While the lowest 
number was recorded on Giza 40 variety with an average 46.83 indiv./5 plants in the first season 2010/2011. In the second season 2011/2012 Sakha 4 variety harboured the highest number of Empoasca spp. with an average 105.57 indiv /5 plants, while the lowest one on Sakha 2 with an average 57.85 indiv $/ 5$ plants

\section{Effect of faba bean components on the insect pests} infestation:

Data presented in Table (5) show the analysis of faba bean varieties and all elements. The highest variety in carbohydrates content was Sakha $4(52.01 \%)$, while the lowest one was Giza $3(46.8 \%)$. Data show the highest variety in protein was Giza $3(20 \%)$, while Sakha 4 contains the lowest percentage of protein $(16.7 \%)$.
Concerning to lipids content, the highest percentage of lipids was recorded in Sakha $2(2.04 \%)$ while the lowest variety in lipids content was Sakha 4 $(0.93 \%)$. The highest variety in silica content was both Sakha 4 and Giza $3(2.7 \%)$, while the lowest one was Sakha 2 variety $(1.4 \%)$.

With regard to phenol content, the highest content was recorded in Giza 40 variety $(0.583 \%)$, while the lowest content for phenol was recorded in Sakha 2 $(0.473 \%)$.

The highest variety in chlorophyll content is Sakha 4 (42.2 ppm), while the lowest variety in chlorophyll content is Giza $3(36.00 \mathrm{ppm})$. These results are similar to those obtained by El-Mashaly (2013) and Abou- Attia et al., (2013).

Table 5. Estimating of carbohydrates, protein, lipids, silica, phenol, chlorophyll, catalase and peroxidase enzymes on faba bean varieties

\begin{tabular}{|c|c|c|c|c|c|c|c|c|c|c|}
\hline \multirow[t]{2}{*}{ Variety } & $\begin{array}{c}\text { Total } \\
\text { carbohydrate }\end{array}$ & $\begin{array}{c}\text { Crude } \\
\text { protein }\end{array}$ & $\begin{array}{l}\text { Total } \\
\text { lipid }\end{array}$ & Silica & $\begin{array}{c}\text { Total } \\
\text { phenol }\end{array}$ & $\begin{array}{c}\text { Chlorophy } \\
\text { ll }\end{array}$ & $\begin{array}{c}\text { Catalase } \\
\text { uninfested }\end{array}$ & $\begin{array}{l}\text { Catalase } \\
\text { infested }\end{array}$ & $\begin{array}{c}\text { Peroxidase } \\
\text { uninfested }\end{array}$ & $\begin{array}{c}\text { Peroxidase } \\
\text { infested }\end{array}$ \\
\hline & \multicolumn{5}{|c|}{$\%$} & \multicolumn{5}{|c|}{ pmm } \\
\hline \multirow{2}{*}{ Sakha2 } & $47.6 \pm$ & $18.4 \pm$ & $2.04 \pm$ & $1.4 \pm$ & $0.473 \pm$ & $36.7 \pm$ & $0.00373 \pm$ & $0.0045 \pm$ & $0.031 \pm$ & $0.0809 \pm$ \\
\hline & $0.05 \bar{b}$ & $0.03 \bar{b}$ & $0.01 \bar{a}$ & $0.3 \mathrm{~d}$ & $0.00 \mathrm{~b}$ & $4.6 \bar{a}$ & $0.00 \mathrm{a}$ & $0.00 \mathrm{a}$ & $0.011 \bar{b}$ & $0.05 \mathrm{a}$ \\
\hline \multirow{2}{*}{ Sakha3 } & $48.7 \pm$ & $17.9 \pm$ & $1.8 \pm$ & $1.7+$ & $0.487 \pm$ & $37.5 \pm$ & $0.00391 \pm$ & $0.0037 \pm$ & $0.0403 \pm$ & $0.041 \pm$ \\
\hline & $0.10 \bar{c}$ & $0.03 \bar{c}$ & $0.03 \bar{b}$ & $0.03 c$ & $0.00 \bar{b}$ & $5.8 \mathrm{a}^{-}$ & $0.00 \mathrm{a}^{-}$ & $0.00 \mathrm{ab}$ & $0.017 \overline{\mathrm{b}}$ & $0.01 \bar{c}$ \\
\hline \multirow{2}{*}{ Sakha4 } & $52.01 \pm$ & $16.7 \pm$ & $0.93 \pm$ & $2.7 \pm$ & $0.518 \pm$ & $42.2 \pm$ & $0.0025 \pm$ & $0.003 \pm$ & $0.109 \pm$ & $0.156 \pm$ \\
\hline & $0.05 \mathrm{a}^{-}$ & $0.03 \bar{f}$ & $0.03 \bar{d}$ & $0.0 \overline{3} \mathrm{a}$ & $0.00 \bar{b}$ & $5.2 \overline{\mathrm{a}}$ & $0.00 \mathrm{ab}$ & $0.00 \mathrm{ab}$ & $0.057 \overline{\mathrm{ab}}$ & $0.02 \bar{b}$ \\
\hline \multirow{2}{*}{ Misr1 } & $49.8 \pm$ & 17.4+ & $1.4+$ & $2.04 \pm$ & $0.495 \pm$ & 41.1_ & $0.0015 \pm$ & $0.00159 \pm$ & $0.019 \pm$ & $0.045 \pm$ \\
\hline & $0.03 \bar{b}$ & $0.00 \overline{\mathrm{d}}$ & $0.0 \overline{3 \mathrm{c}}$ & $0.03 \bar{b}$ & $0.00 \bar{b}$ & $6.4 \overline{\mathrm{a}}$ & $0.00 \mathrm{ab}$ & $0.00 \mathrm{bc}^{-}$ & $0.051 \overline{\mathrm{a}}$ & $0.01 \bar{c}$ \\
\hline \multirow{2}{*}{ Giza 40} & $48.3 \pm$ & $17.3 \pm$ & $2.03 \pm$ & $2.1 \pm$ & $0.583 \pm$ & $37.5 \pm$ & $0.0039 \pm$ & $0.0015 \pm$ & $0.031 \pm$ & $0.068 \pm$ \\
\hline & $0.08 \overline{\mathrm{d}}$ & $0.08 \overline{\mathrm{e}}$ & $0.02 \bar{a}$ & $0.03 \bar{b}$ & $0.02 \bar{a}$ & $4.1 \overline{\mathrm{a}}$ & $0.00 \mathrm{a}$ & $0.00 \mathrm{bc}$ & $0.00 \bar{b}$ & $0.00 \overline{b c}$ \\
\hline \multirow{2}{*}{ Giza3 } & 46.8+ & $20 \pm$ & $1.8 \pm$ & $2.7 \pm$ & $0.506 \pm$ & $36 \pm$ & $0.0015 \pm$ & $0.0005 \pm$ & $0.022 \pm$ & $0.085 \pm$ \\
\hline & $0.05 \overline{\mathrm{f}}$ & $0.0 \overline{1} \mathrm{a}$ & $0.05 \bar{b}$ & $0.0 \overline{3} \mathrm{a}$ & $0.00 \mathrm{~b}$ & $6.9 \mathrm{a}$ & $0.00 \mathrm{~b}$ & $0.00 \mathrm{c}$ & $0.63 \overline{\mathrm{a}}$ & $0.00 \overline{b c}$ \\
\hline
\end{tabular}

In the same column, means followed by the same letter are not significantly different at $5 \%$ level according to Duncan's multiple range test

Correlation between faba bean components and insect pests :

The data presented in Table ( 6 ) show the simple correlation coefficient among faba bean varieties and some components of faba bean plants and population of Liriomyza trifolii and Empoasca spp. during the first and second season. The insect population larvae of $L$. trifolii correlated insignificantly negative with total carbohydrate and chlorophyll in both seasons and addition to protein \& silica in the second season. Positive insignificant correlation was recorded with lipids and phenol in both seasons, while with protein in the first season.

Jassid, Empoasca spp. population density correlated positive insignificant with total carbohydrates , silica, phenol, and chlorophyll in the first season, but negatively insignificant with total carbohydrates, phenol and chlorophyll in the second season. Results are similar to those obtained by Ibrahim (2008), ElMashaly(2013) and Abou- Attia et al.,(2013).

\section{Analysis of physiological traits:}

1- Analysis of catalase (CAT) activity

The results of activity studies in Fig. (5 ) revealed that the activities of antioxidant CAT enzymes of the 6 tested faba bean varieties were increased in leaves under insect infestation stress. The responses of CAT activity in some tolerant varieties such as sakha 2, sakha 3,and sakha 4 for infestation by leafminer Liriomyza trifolii and Jassids Empoasca spp. The infestation tolerances were higher than its activity in infestation sensitive varieties such as Giza 40, Giza3 and Misr 1 for Liriomyza trifolii . while Misr1 and Giza 40 in case of jassids under infestation stresses

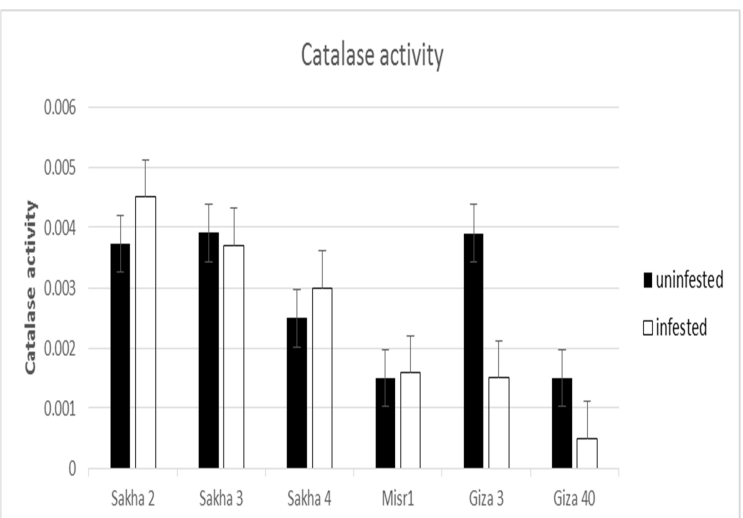

Fig. 5. Effect of infestation stress on catalase activity of 6 tested faba bean varieties

1. Analysis of peroxidase (POX) activity:

The results in Fig. (6 ) showed that the highest activity of POX enzymes was observed in the tolerant varieties such as sakha 2 and sakha 4 varieties which possessed the highest tolerance to infestation stress among the 6 studied varieties for L.trifolii and Empoasca spp. infestation increase in POX activity under infestation condition has been linked with protection from oxidative damage. Antioxidants are directly involved in the changes 
taking place in the plant under infestation stress. From previous results it possible to concluded that the CAT enzymes showed the highest rate of activity changes under infestation stress than of POX activity.

This indicated the major role of CAT enzyme in the antioxidant defense of faba bean plants in infestation stress conditions. Population of L.trifolii larvae correlated insignificantly positive with catalase and peroxidase enzymes in the first season, while positive significant with catalase and negative significant with peroxidase enzymes in the second season. Population of Jassids showed negative significant correlation with CAT and POX in the first season, while negative nonsignificant in the second season.

Results are similar to Felton et al .,1994, Mittler, 2002; Ralph et al., 2004, Felton, 2005; Hanley et al .,2007 and Chen, 2008.

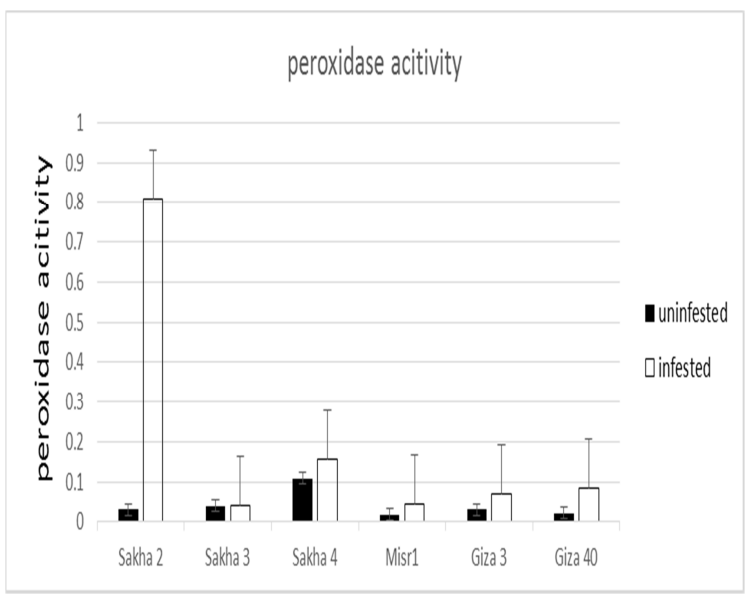

Fig. 6. Effect of infestation stress on peroxidase activity of 6 tested faba bean varieties

Table 7. Simple correlation coefficient values between faba bean insect pests and some components of faba bean varieties

\begin{tabular}{|c|c|c|c|c|c|c|c|c|c|}
\hline \multirow{2}{*}{ Variety } & \multirow{2}{*}{ Season } & T. carbohydrate & C. protein & T. lipid & Silica & T. phenol & Chlorophyll & Catalase & Peroxidase \\
\hline & & \multicolumn{8}{|c|}{$\mathbf{p p m \%}$} \\
\hline \multirow{2}{*}{ Liriomyza } & $2014 / 15$ & $-0.314 \mathrm{~ns}$ & $0.396 \mathrm{~ns}$ & $0.209 \mathrm{~ns}$ & $0.430 \mathrm{~ns}$ & $0.368 \mathrm{~ns}$ & $-0.464 \mathrm{~ns}$ & $0.012 \mathrm{~ns}$ & $0.022 \mathrm{~ns}$ \\
\hline & $2015 / 16$ & $-0.366 \mathrm{~ns}$ & $-0.015 \mathrm{~ns}$ & $0.496 \mathrm{~ns}$ & $-0.485 \mathrm{~ns}$ & $0.139 \mathrm{~ns}$ & $-0.203 \mathrm{~ns}$ & 0.0749 & -0.8047 \\
\hline \multirow{2}{*}{ Jassid } & $2014 / 15$ & $0.325 \mathrm{~ns}$ & $-0.455 \mathrm{~ns}$ & $-0.253 \mathrm{~ns}$ & $0.4005 \mathrm{~ns}$ & 0.7308 & 0.4645 & -0.3130 & -0.0193 \\
\hline & $2015 / 16$ & $-0.0001 \mathrm{~ns}$ & $0.1349 \mathrm{~ns}$ & $0.1193 \mathrm{~ns}$ & $0.0289 \mathrm{~ns}$ & $-0.2953 \mathrm{~ns}$ & $-0.0295 \mathrm{~ns}$ & $-0.2318 \mathrm{~ns}$ & $-0.22604 \mathrm{~ns}$ \\
\hline
\end{tabular}

\section{REFERENCES}

Abou-Attia, F. A. M. (2006), Population density and host preference of some piercing sucking pests in response to different leguminous varieties. J. Agric. Sci., Mansoura Univ., 31 (7): 4661- 4677.

Abou-Attia, F. A;I. A. Khodir and A. S. R.; Hatem .(2013) .Effect of chemical componnents and morphological characterist 3 ics of faba bean and soybean varieties on insect pest infestation. Egy.J.Plant Pro.Res.1(4).

APHA (1992). Standard methods for the estimation of water and plant $18^{\text {th }}$ edd American Public Health Association Washington Dc. U.S.A.

A.O.A.C. (1984). Official methods of analysis $13^{\text {th }} \mathrm{Ed}$ Published by the Association of Official Analytical Chemists. Washington Dc. U.S.A.

Awadalla, S. S.; F. E. Abdallah and Nora R. El-Mashaly (2013). Influence of some varieties on the main insect pests attacking faba bean plants. J. plant Prot. and Path., Mansoura Univ., 4(6): 581- Bassiony A. Rowfida, F.A. Abou-Attia, M.A. Samy, Youssef, E. Asmhan and T. Ueno (2017). Parasitoid Wasps Attacking the American Serpentine Leafminer 589.

Bastawisy,M.;M .A.Abdel -rassal; S.H.Mansor; and M.M.Hady (1998)Performance of some faba bean genotypes on some yield and its components and sensitivity for some insect pests .Annals of Agric .Sci Moshtohor ,36(1): 675-682.

Bassiony, A . Rowfida ,F.A. Abou-Attia ,M.A.Samy, Youssef ,E.Asmhan and T.Ueno (2017).Parasitoid wasps attacking the American serpentine leafminer Liriomyza trifolii in Kafr El- Shiekh ,Egypt, Inter .J.Zool .Investigations 2.(1):15-20
Bernays, E. A. (1999). When host choice is a problem for a generalist herbivore: experiments with the whitefly, Bemisia tabaci. Ecological Entomology, 24: 260 267.

Calvetti, M. and P. C. Remotti (1998). Host preference and performance of Bemisia aregentifolii (Homoptera: Aleyrodidae) on weeds in central Italy. Environ. Entomol., 27: 1350- 1356.

Chen, M. S. (2008). Inducible direct plant defense against insect herbivores: A review. Insect Science, 15: 101-114.

Duncan.B.D, (1955). Mulitiple range and multiple $\mathrm{F}$ test Biometrics. 11:1-42.

El-Gindy,M.A.A.(2002). Studies on certain Homopterous incect vectors of plant pathogen diseases. ph.D.Thesis Plant Protection Dept., Fac .of Agric, Zagazig Univ.

El-Mashaly, R.A.Nora (2013). Influence of some agricultural practices on the main insect pests attacking faba bean and their natural enemies. Ph. D. Thesis, Fac. Agric., Mansoura Univ., 199pp.

El-Samahy, M. F. M. (2008) Studies on faba bean aphid, Aphis craccivora and faba bean leaf miner, Liriomyza trifolii and their natural enemies at Kafr El-Sheikh Governorate. Ph. D. Thesis, Fac Agric., Tanta Univ., 167 pp.

Felton, G. W. (2005). Indigestion is a plant's best defense. Proceedings of the National Academy of Sciences of the United States of America., 102: 18771-18772.

Felton, G. W.; Bi, J. L.: Summers, C. B.; Mueller, A. J. and Duffey, S.S. (1994). Potential role of lipoxygenases in defense against insect herbivory. Journal of Chemical Ecology, 20: 651- 666. 
Gamieh, G. N. and A. A. El- Basuony (2001). Population densities of piercing sucking pests in soybean fields as influenced by varieties, predators and leaf physical and chemical properties. J. Agric. Sci., Mansoura Univ., 26 (2): 1089 -1099.

Hanely, M. E.;B.B.; Lamont, M.M.; Fairbanks, and C.M. Rafferty, (2007). Plant structural traits and their role in antiherbivore defense. Perspec. Plant. Ecol. Evol. Syst, 8: 157-178.

Hatem,A.S.R.(2014). Studies on insect pests infesting leguminous plants and their natural enemies at Kafr El-shekh.M .Sc. Thesis, 174 pp.

Hedge. I. E. and B. T. Hofreiter (1962). Carbohydrate Chemistry 17 (Eds Whistler, R.L. and Be Miller, J. N.). Academic Press New York.

Helal,H.A.; A. S. El-Khouly;E. M. E. Khalafalla; M. M. Metwally and A.B. El-Mezaien (1997). Preliminary studies on the population of legume aphid ,Aphis craccivora (Koch) and jassids ,Empoaca spp.. on different faba bean varieties and breeding lines under the field condition at Kafr El-Sheikh Governorate ,Egypt .Egyptian. J. Agric.Res. 75(4) : 951-959.

Ibrahim , S.M. Amira (2008). Studies on faba bean leafminer L.congesta (Beck) in Kafr El-Sheikh Governorate. Ph. D. Thesis, Fac. of Agric. Tanta Univ., 106 pp.

Jones, I. R.; I Benton; B. Wolf and H.A. Mills (1991). Plant analysis Handbook, Methods of plant analysis and inter - predation Micro- Macro. Publishing, inc, USA. P. 30-34.
Lobarzwski, j, m. Brzyska and A.wojcik(1990). The influence of metal ions on The soluble and immbolized cytoplasmic cabbage peroxides activity and its kinetics. J.Mol.Catal., 59:373-383.

Malick, C.P. and M.B.Singh (1980). Plant Enzymology and Histo Enzymology Kalyari Publishers News Delhi P,286.

Mesbah, I,I. and M. R. Sherif (1994). Susceptibility of faba bean varieties to leafminer $L$. congesta (Beck) infestation and effect of chemical control on infestation and yield .J.Agric Res ; Tanta . Univ .20(3): 524-529.

Metwally, M.M.; E.M.E. Khalafalla; H.A. Helal; A.S.ElKhouly and A.B. El-mazaien (1997). Susceptibility of some faba bean varieties and breeding lines to infestation with Aphis craccivora (Koch) and Empoasca spp under field conditions of Kafr ElSheikh Governorate, Egypt. Egyptian. J. Agric. Res., 75(3):579-586.

Mitller, R. (2002). Oxidative stress, antioxidants and stress tolerance. Trends Plant Sci., 7: 405- 410.

Ralph, J.;M.Bunzel,J.M.,Marita,R.D., Hatfield, F. Lu, H.Kim, P.F.,Schatz, J.H.Grabber, and H.Steinhart,(2004).Peroxidase- dependent crosslinking reactions of $\mathrm{P}$ - hydroxycinnamates in plant cell walls. Phytochemistry Reviews, 3: 79-96.

Sadasivam ,S. and A.Manickam (1996). Biochemical methods New Age International Publishers (P)Ltd., New Delhi, India.

\section{Liriomyza الوفرة الموسمية و حساسية بعض أصناف الفول البلاي للاصابة بحشرة صانعة أنفاق أوراق الفول trifolii}

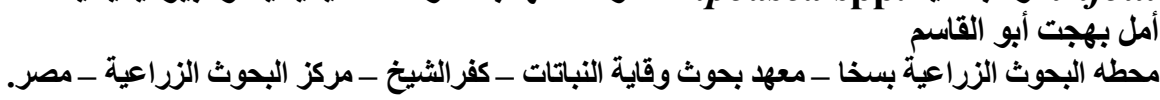

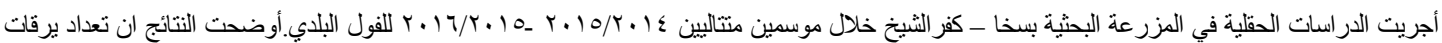

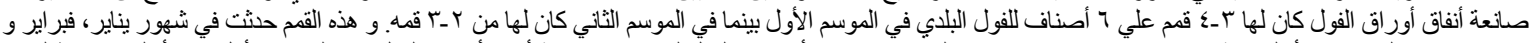

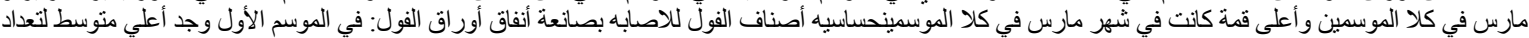

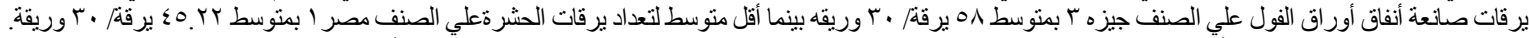

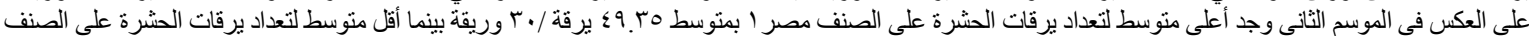

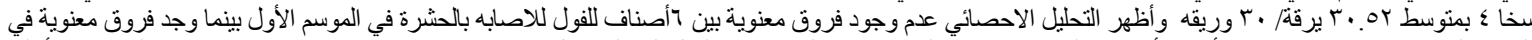

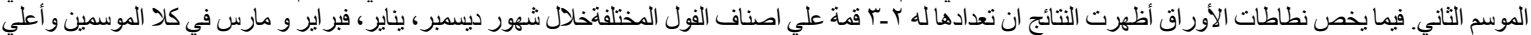

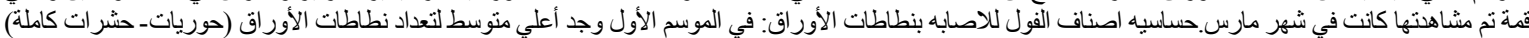

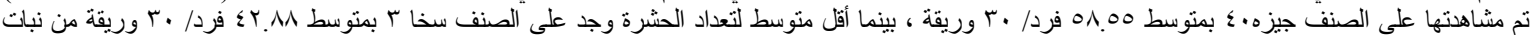

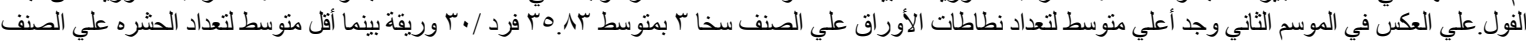

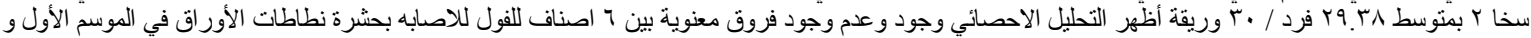

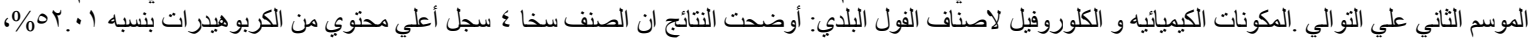

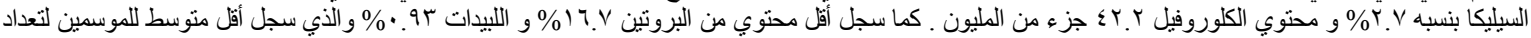

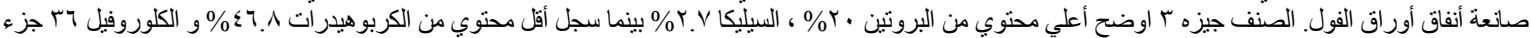

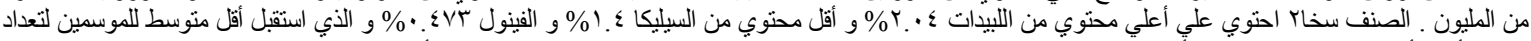

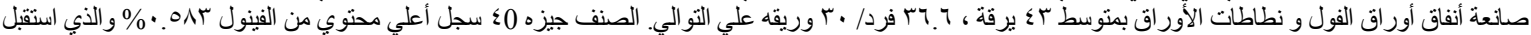

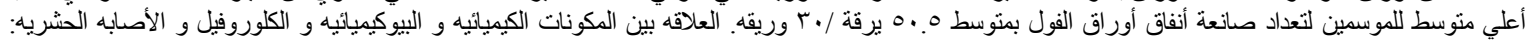

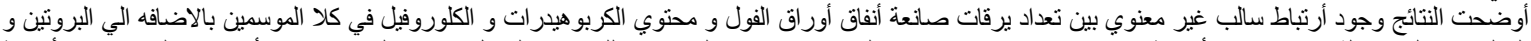

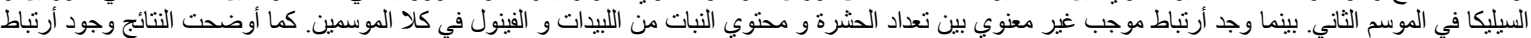

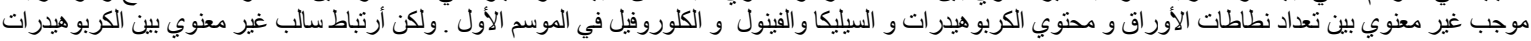

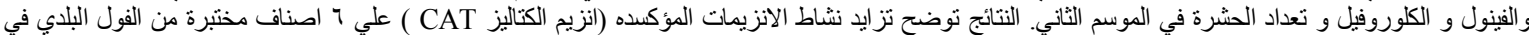

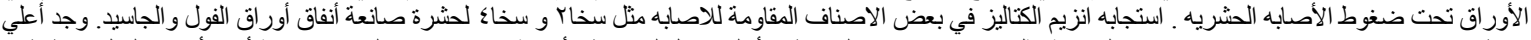

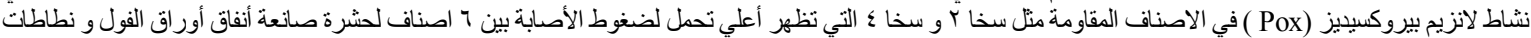

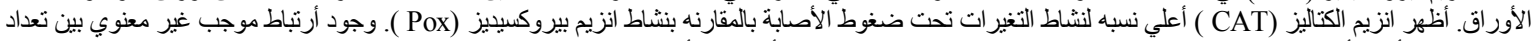

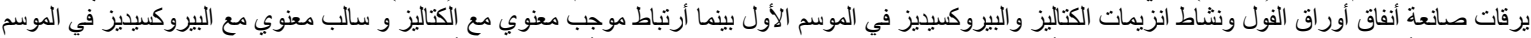

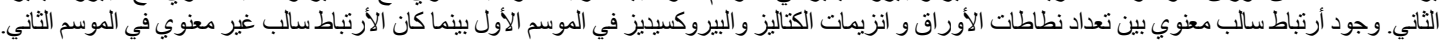

